Original Research Paper

\title{
Morphogenesis in Tissue Culture of Local Kazakh Cotton Varieties
}

\author{
Bishimbayeva Nazira, Yertayeva Bakhyt, Amirova Aigul and Rakhimbayev Izbasar \\ RGI "Institute of Plant Biology and Biotechnology" Kazakhstan
}

Article history

Received: 09-06-2017

Revised: 30-06-2017

Accepted: 08-07-2017

Corresponding Author:

Yertayeva Bakhyt

RGI "Institute of Plant Biology

and Biotechnology"

Kazakhstan

Email: bahyt.ertaeva@mail.ru

\begin{abstract}
Callus was initiated from hypocotyl and cotyledon explants of seven of commercial Kazakh cotton cultivars on MS medium supplemented with $0,1 \mathrm{mg} \mathrm{L}^{-1} 2,4-\mathrm{D}$ and $0,5 \mathrm{mg} \mathrm{L}^{-1}$ kinetin. The percentage of callus formation ranged from 64,0 to $91,0 \%$ for cotyledons and from 72 to $90 \%$ for hypocotyls. Study of morphological heterogeneity peculiarities of metamorphosis and histological structure of calli of cotton allowed to identifying seven tissues types and selecting the morphologically stable and perspective callus type for embryogenesis. Significant differences between the calli types of cotton were found by histological and morphological comparative analysis.
\end{abstract}

Keywords: Cotton, Histology, Pro-Embryos, Globular Embryos, Somatic Embryogenesis

\section{Introduction}

Morphogenesis in plant cell and tissue culture can occur through somatic embryogenesis or organogenesis (formation of roots and shoots) (Vasil, 1987). Somatic embryogenesis is the main method of micropropagation of plants in vitro.

Somatic embryogenesis is a process in which somatic cells of plants reprogrammed and passed through various stages of embryogenesis forming embryos (bipolar structures) that resemble zygotic embryos (Williams and Maheswaran, 1986; Jiménez, 2001). Cotton is one of the most recalcitrant species to obtain somatic embryogenesis and plant regeneration though embryogenic calli, compared with many other crops (Sakhanokho et al., 2004; Ghasemi et al., 2007; 2011). The first report on inducing somatic embryogenesis in cotton (Gossypium koltzchianum) was described by Price and Smith (1979). Successful plant regeneration from undifferentiated callus of cotton cv. Coker 310 (Gossypium hirsutum L.) via somatic embryogenesis was reported by Davidonis and Hamilton (1983). Regenerated plants of cotton have been obtained from several varieties such as T25, GSA 78 and Acala with low plant regeneration capacity (Rajasekaran et al., 2004).

Although cotton tissue culture reaches plant regeneration through somatic embryogenesis, some issues still remain. Genotype dependent response restricts the application of cotton in genetic transformation (Wilkins et al., 2000). The most of work are limited to highly regenerable cotton genotypes cv. Coker and its derivatives. The earlier regeneration protocol have standardized only for Coker genotypes (Ganesan et al., 2006).

The scientists of many countries studied the process of callusogenesis and morphogenesis of cotton and tried entry cottons into the world of biotechnology (Kumria et al., 2003; Ikram-ul-Haq, 2005; Wu et al., 2005; Ganesan et al., 2006; Hilarie et al., 2008; Ghaemi et al., 2011). The main problem limiting widespread use of cell technologies for the genetic improvement of cotton is high dependency on in vitro plant regeneration from the initial genotype. In this regard, one of the main tasks of the modern plant biotechnology is to identify common cytophysiological regularities of in vitro morphogenesis universal for different cotton genotypes. In order to understand the processes of somatic embryogenesis, it is necessary to change the composition of the medium and observe the progress in development of embryo using histological slides. The present study designed to study the callus induction morphological heterogeneity, peculiarities of metamorphosis of calli, development of somatic embryogenesis of local cotton genotypes.

\section{Materials and Methods}

\section{Plant Materials}

Plant materials of seven commercially grown cotton (Gossypium hirsutum L.) cultivars (Maktaaral-4003, 
Maktaaral-4005, Maktaaral-4006, Maktaaral-4007, Maktaaral-4011, Maktaaral-4019, Paktaaral-3044) were provided by the Cotton Growing Research Institute of Maktaaral in South-Kazakhstan.

\section{Seed Sterilization}

Delinted cotton seeds were surface sterilized with $50 \% \mathrm{H}_{2} \mathrm{SO}_{4}$ for $5 \mathrm{~min}$, followed by $\mathrm{NaOCl}$ (shaken for $20 \mathrm{~min}$ at $110 \mathrm{rpm}$ ), rinsed three times with distilled sterile water. The sterilized seeds were plated on MS (Murashige and Skoog, 1962) medium with 0,1 mg $\mathrm{L}^{-1}$ kinetin (Kumria et al., 2003) and 1,0\% sucrose and then cultured in an incubator at $28,0 \pm 2,0^{\circ} \mathrm{C}$ up to formation of seedlings.

\section{Experimental Procedure}

Explants for callus initiation were used segments of hypocotyl (0,5-0,7 cm sections) and cotyledon (1,5-2,0 $\mathrm{cm}$ sections) was cut from 5-7 days-old sterile seedlings of cotton. These hypocotyl and cotyledon segments were aseptically transferred to callus induction medium MS supplemented with $0,1 \mathrm{mg} \mathrm{L}^{-1}$ 2,4-D and $0,5 \mathrm{mg} \mathrm{L}^{-1}$ kinetin (Kumria et al., 2003). Explants were incubated $4-5$ weeks at $28 \pm 2{ }^{\circ} \mathrm{C}$ temperature under $16 \mathrm{~h}$ light and $8 \mathrm{~h}$ dark (Fig. 1).

Callus tissues have subcultured for induction of somatic embryogenesis on different MS media:

- MS with twice concentration of $\mathrm{KNO}_{3}$ and 3,0\% maltose

- $\quad$ MS with $1 / 5$ part of mineral salts and 1,0\% maltose;

- MS with 1,0 mg L $\mathrm{mg}^{-1}$ 2,4-D, 500,0 $\mathrm{mg} \mathrm{L}^{-1}$ 1-proline and $1000,0 \mathrm{mg} \mathrm{L}^{-1}$ casein hydrolysate

- MS content double strength of mineral elements with 1,0 $\mathrm{mg} \mathrm{L}^{-1} 2,4-\mathrm{D}, 500,0 \mathrm{mg} \mathrm{L}^{-1}$ 1-proline and $1000,0 \mathrm{mg} \mathrm{L}^{-1}$ casein hydrolysate

Histological sectioning was performed according to method of Pausheva (1988). For the histological study, different types of callus in three replicates were taken. The tissues were fixe in fixative solutions, formalinacetic acid-alcohol and then dehydrated in a graded ethanol series, chloroform and embedded in paraffin wax. The sections were cut in $2,0 \mu \mathrm{m}$ using a microtome, then mounted on the slides and stained with Schiff's reagent, hematoxylin and alcian blue (Kamelina et al., 1992). The stained samples were observed under light microscope (Micros MC 300, Austria).

\section{Results and Discussion}

Explants of all cotton cultivars formed callus tissues at high frequencies on MS media with $0,1 \mathrm{mg} \mathrm{L}^{-1} 2,4-\mathrm{D}$ and $0,5 \mathrm{mg} \mathrm{L}^{-1}$ kinetin. The percentage callus formation ranged from 64 to $91 \%$ for cotyledons and from 72,0 to 90,0\% for hypocotyls (Fig. 2).

The histological sections of induction of calli from hypocotyl were represented in image (Fig. 3a). The hypocotyl tissues consisted of vascular bundle cells of trachea and xylem stained by red and blue colors. Callus cells appeared on the surface of hypocotyl tissue consist of young parenchyma cells (Fig. 3b).

Previously, there were 7 types of calli identified (Bishimbayeva, 2007). The strategy this research work development genotype independent regeneration technologies, therefore they have been revealed common cytophysiological features of the regulation of somatic embryogenesis and regeneration on various genotype of wheat and barley. Development of genotype independent technology in vitro cotton plant regeneration could be achieved on this base.

They differed in the morphology and characteristics: I - grayish-white friable morphogenic; II - off-white opaque dense nonmorphogenic; III - brown nonmorphogenic; IV - grayish-white globular morphogenic; V - yellowish translucent friable embryogenic, VI - white opaque embryogenic and VII green compact embryogenic calli. In this study, we will focus on more details of the metamorphosis and histology of callus tissues of cotton.

After 4 weeks, grayish-white friable morphogenic (I type) callus formed grayish-white globular morphogenic callus (IV type) (Fig. 3) upon transfering to MS medium with double strength of mineral elements in addition to $1,0 \mathrm{mg} \mathrm{L}^{-1} 2,4-\mathrm{D}, 500,0 \mathrm{mg} \mathrm{L}^{-1}$ l-proline and $1000,0 \mathrm{mg} \mathrm{L}^{-1}$ casein hydrolysate. Yellowish translucent friable embryogenic (V type) callus were obtained from type I callus when it was cultured for 4 weeks on MS medium with twice concentration of $\mathrm{KNO}_{3}$ and 3,0\% maltose (Fig. 4).

The off-white opaque dense nonmorphogenic (II type) and brown nonmorphogenic (III type) calli were difficult to subculture as they began to brown and grew poorly on the maintenance medium.

Upon subculture, the grayish-white globular morphogenic tissue (IV type) developed two new embryogenic calli (VI and VII types). After 4-5 weeks subculture on MS medium with $1,0 \mathrm{mg} \mathrm{L}^{-1}$ 2,4-D, 500,0 $\mathrm{mg} \mathrm{L}^{-1}$ l-proline and $1000,0 \mathrm{mg} \mathrm{L}^{-1}$ casein hydrolysate the IV type callus transferred to white opaque embryogenic tissue (VI type). The green compact embryogenic callus (VII type) obtained in resulting of successive subcultures on MS medium content twice concentration of $\mathrm{KNO}_{3}$ and $3 \%$ maltose than on $\mathrm{MS}$ medium with $1 / 5$ part of mineral elements and 1,0\% maltose according to protocol (Kumria et al., 2003). The same metamorphosis ways and types of tissue were used for all varieties studied. 


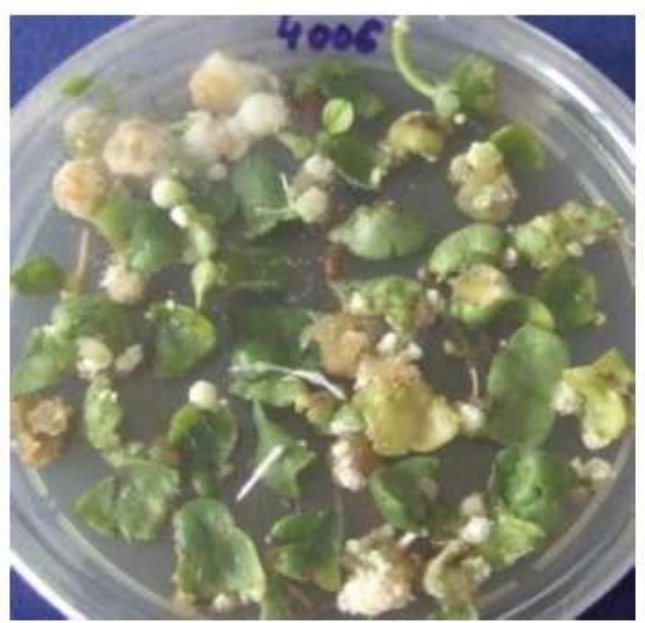

(a)

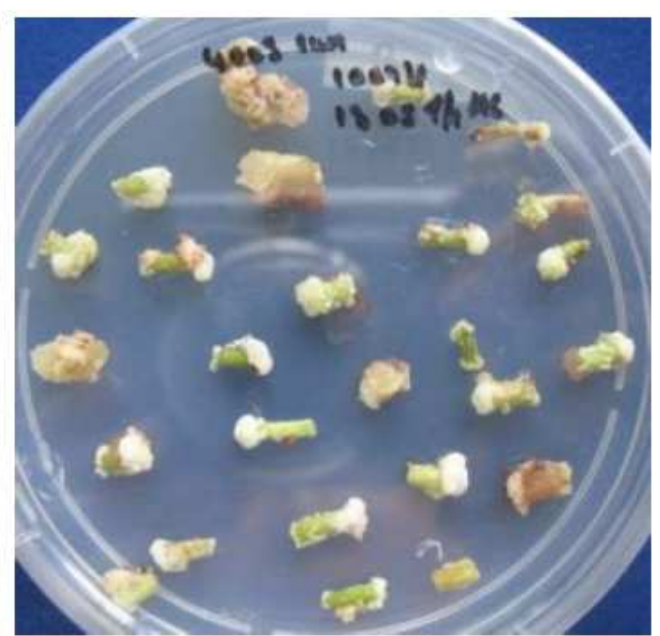

(b)

Fig. 1. Primary calli originating from hypocotyl and cotyledon segments after 4-5 week; (a) cotyledon segments (b) hypocotyl segments

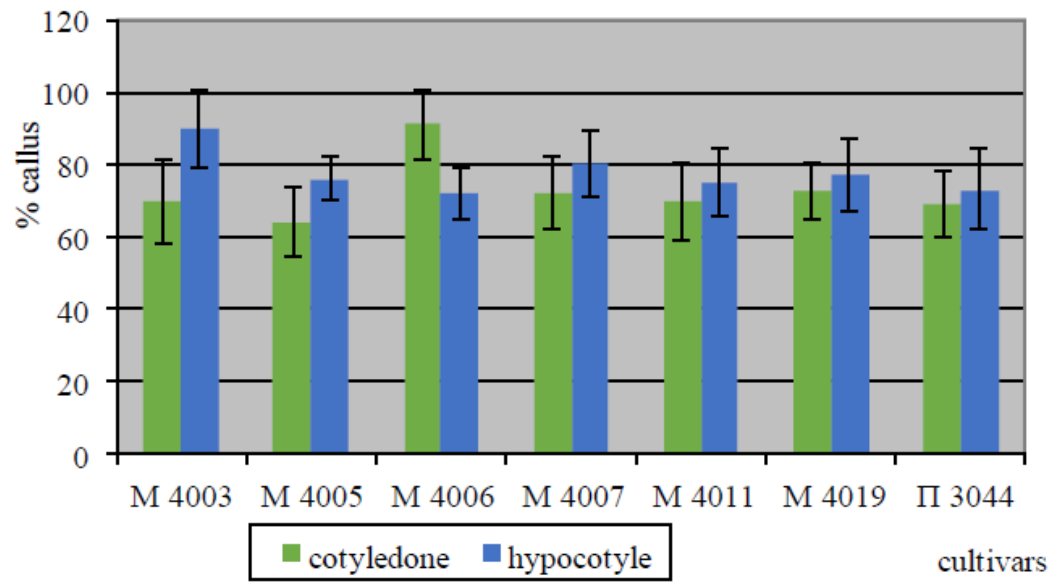

Fig. 2. Callus formation from different explants of local cotton cultivars on MS medium supplemented with $0,1 \mathrm{mg} \mathrm{L}^{-1} 2,4-\mathrm{D}$ and $0,5 \mathrm{mg} \mathrm{L}^{-1}$ kinetin
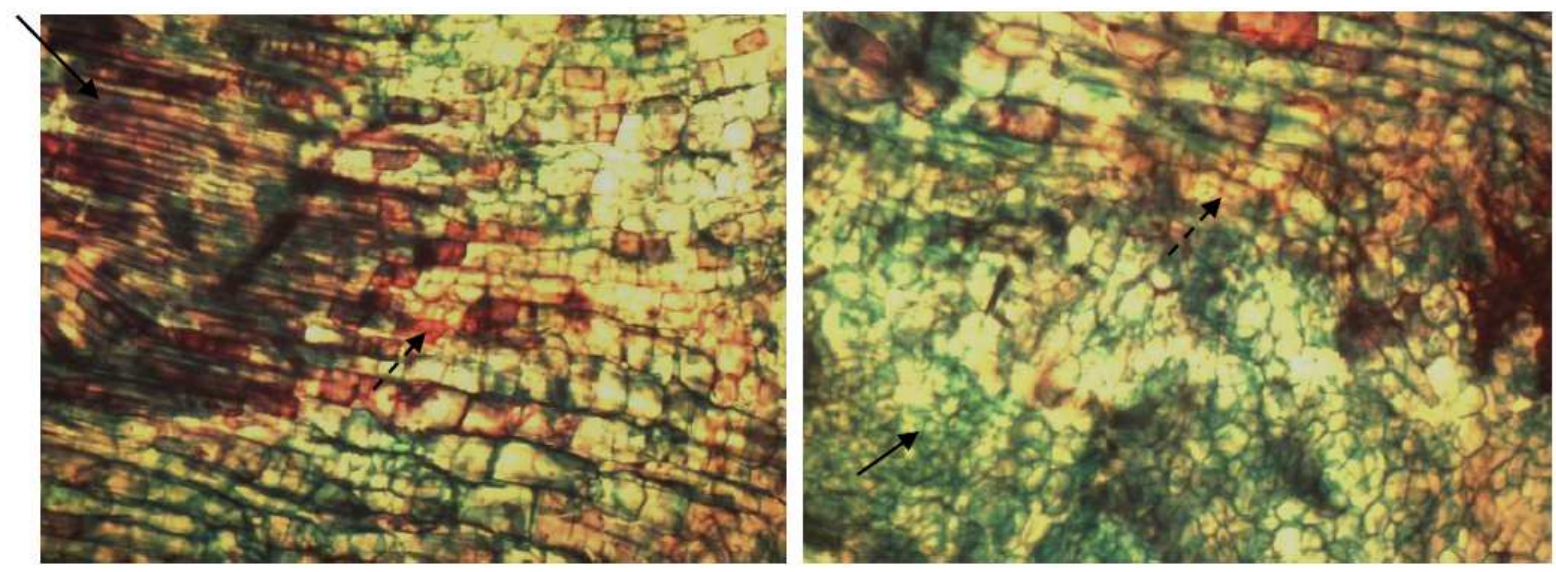

Fig. 3. Hystologycal sections of callus induction from hypocotyl of cotton; (a) explant structure (hypocotyl), (b) induction of callus cells from explant; $--\rightarrow-$ vascular bundle cells, $\rightarrow-$ callus cells 


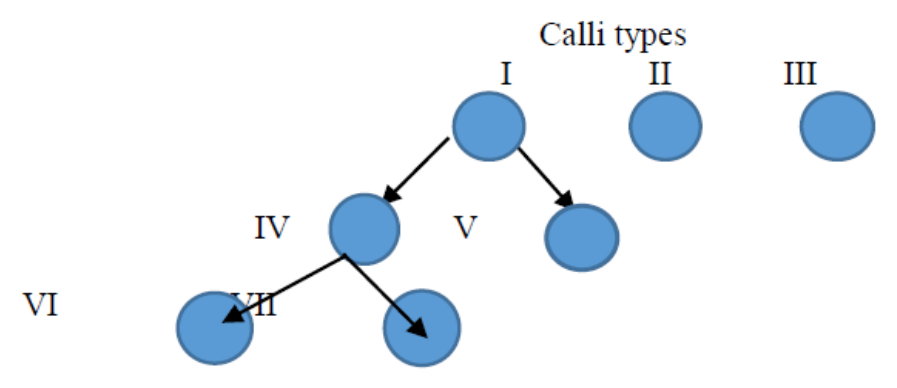

Fig. 4. Scheme of metamorphosis of calli of cotton; I - grayish-white friable morphogenic, II - off-white opaque dense nonmorphogenic, III - brown nonmorphogenic, IV - grayish-white globular morphogenic, V - yellowish translucent friable embryogenic, VI - white opaque embryogenic and VII - green compact embryogenic calli

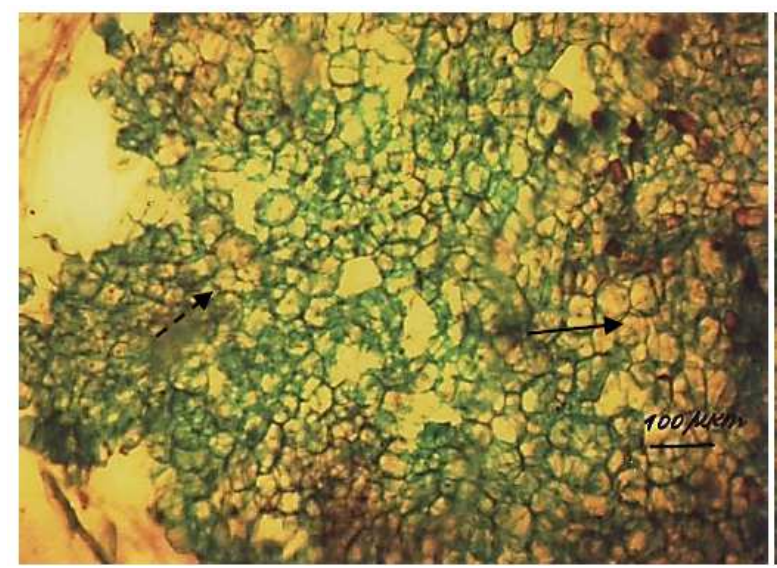

(a)

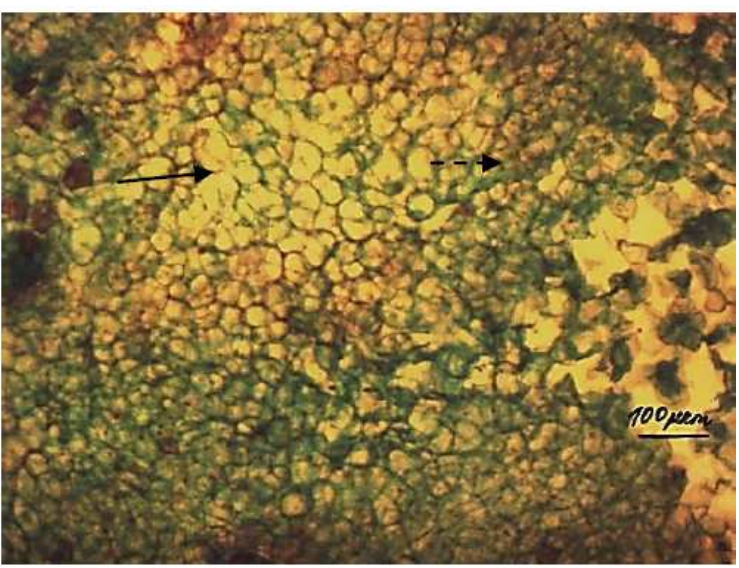

(b)

Fig. 5. Structure of grayish-white friable morphogenic calli (I type); $--\rightarrow$ - meristem cells, $\longrightarrow$ - parenchyma cells

In results, the grayish-white friable morphogenic (I type) selected as morphological perspective callus type and responsive to changes of media composition and suitable for embryogenic callus formation. On the different media detected variation of colour and density of induced embryogenic calli. These results tend to support the difference response of plant cells to change of media condition that suggest the morphogenesis processes in vitro can be regulating.

With a view to know the initiation of somatic embryogenesis and progress of embryo differentiation on different media provided histological study. The grayishwhite friable morphogenic callus (I type) composed parenchyma cells $(50-60 \mathrm{mkm})$ which covered by meristem cells $(20-25 \mathrm{mkm})$ and at the periphery of tissues were separated into elongated (105-147 mkm) and spherical cells $(30-50 \mathrm{mkm})$ (Fig. 5). The presence of meristem cells indicates morphogenetic potential of calli and their possibility to somatic embryogenesis induction.

In the structure of II (off-white opaque dense nonmorphogenic) and III types (brown nonmorphogenic) of tissues often were found elements of vascular bundle cells and centers of root formation. Therefore, these tissues considered non-perspective to morphogenesis.
Histological examination of grayish-white globular morphogenic (IV type) callus showing form of globular somatic embryo separated from meristematic center of tissues. Analysis of the globular somatic embryo detected the visible isodiametric cell with prominent nucleus and dense cytoplasm that are the characteristic of embryogenic cells. Thus, strongly suggest the embryogenic nature of this type and characterized as embryogenic callus. Many of isolated cells were shaped oval $(50-70 \mathrm{mkm})$, elongated (70-110 $\mathrm{mkm})$ and single competent to embryogenesis cells $(32-42 \mathrm{mkm})$ at the periphery of tissue. Perhaps, in this type of callus, the embryos appeared from meristematic centers and isolated single cells at the periphery of tissues that characterize both unicellular and multicellular origin of embryos (Fig. 6).

The yellowish translucent friable embryogenic (V type) callus consist of a single embryogenic cells (55-65 $\mathrm{mkm}), 2-, 3-$ and 4-cells pro-embryos (100-160 mkm) pro-globular somatic embryo (160-200 mkm and 330$380 \mathrm{mkm}$ ) and at the periphery of cell complexes of tissue elongated cells (123-141 mkm) (Fig. 7). This type of callus characterizes the initiation of somatic embryos and begins the differentiation with the formation of pro- 

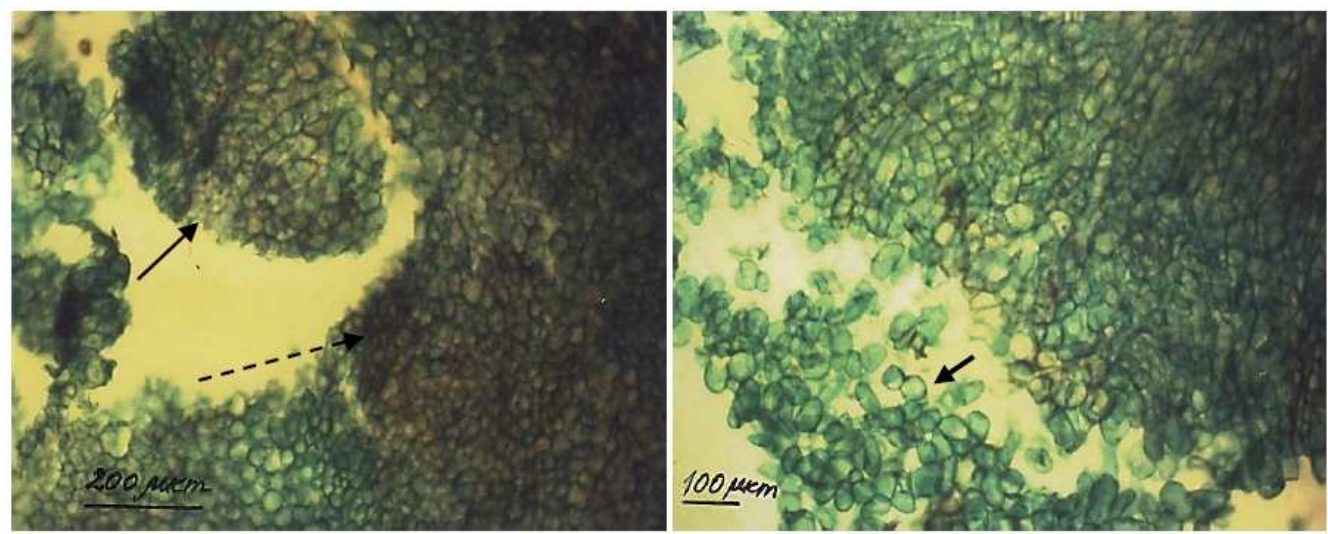

Fig. 6. Histological examination of grayish-white globular morphogenic (IV type) callus; (a) Histological examination globular somatic embryo showing globular somatic embryo, (b) isolated cells at the periphery of tissues: $\rightarrow-$ meristem center, $--\rightarrow$ globular somatic embryo, $\longrightarrow$ - separate callus cells.
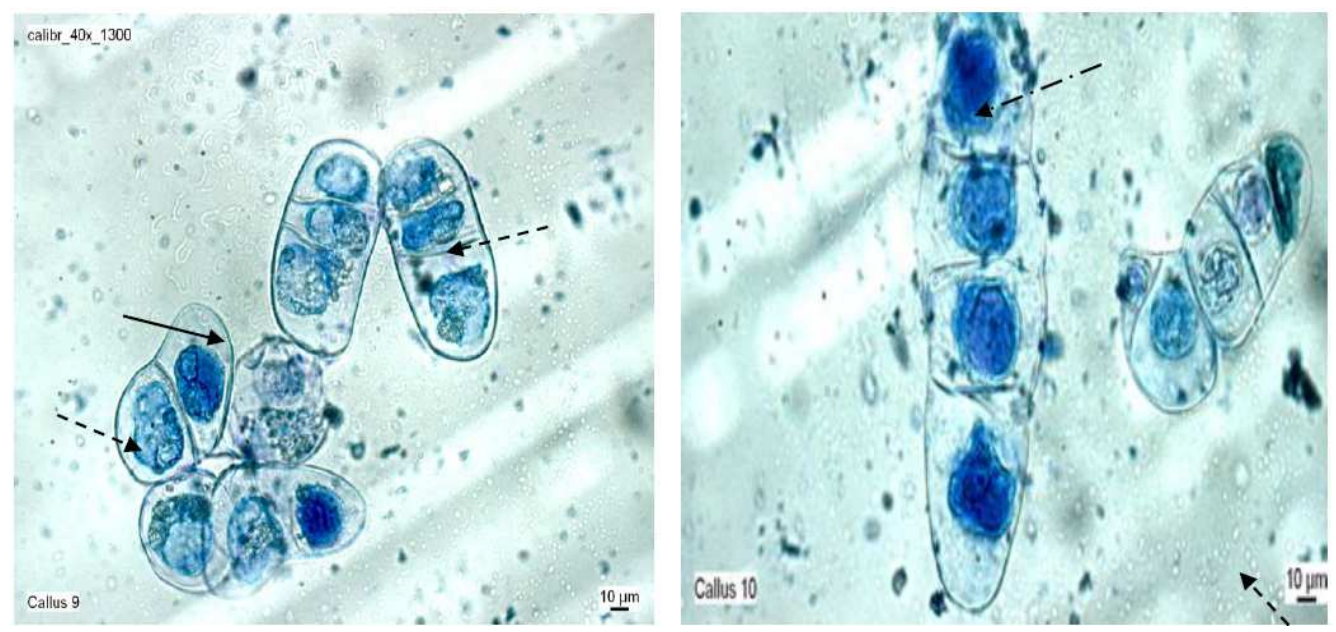

Fig. 7. Histological aspect of yellowish translucent friable embryogenic (V type) callus; $\longrightarrow$ single embryogenic cell; $--\rightarrow 2-, 3-$ and 4-cells pro-embryos; $-\cdot \rightarrow$ pro-globular somatic embryo

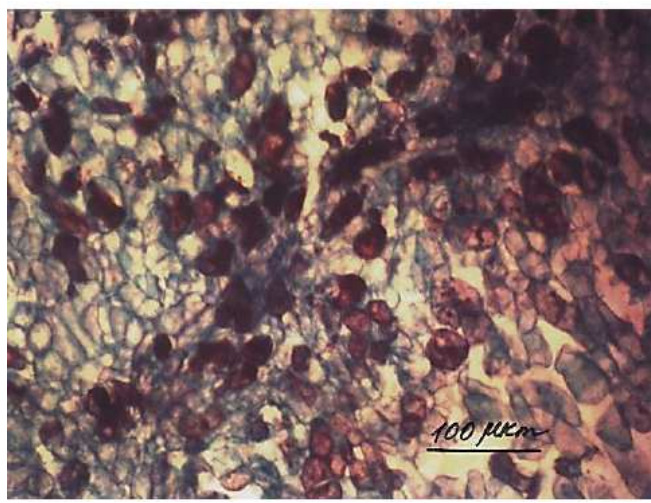

(a)

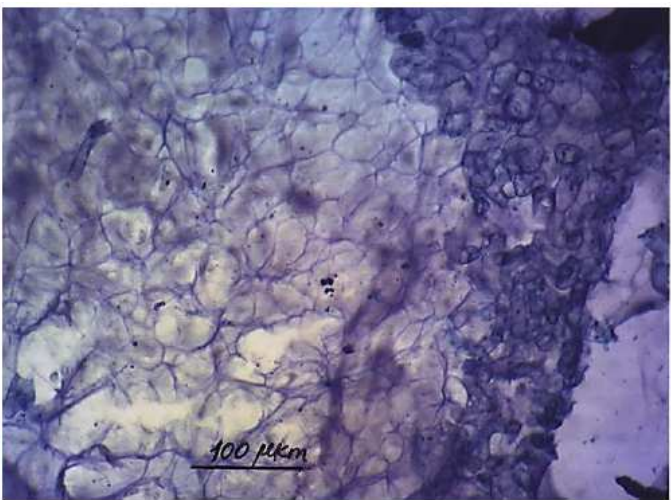

(b)

Fig. 8. Histological analysis showing cell complex in yellowish translucent friable embryogenic (V type) callus of cotton; (a) isolation of single cells from cell complex, (b) - the presence of cells with signs of cell death in cell complexes 


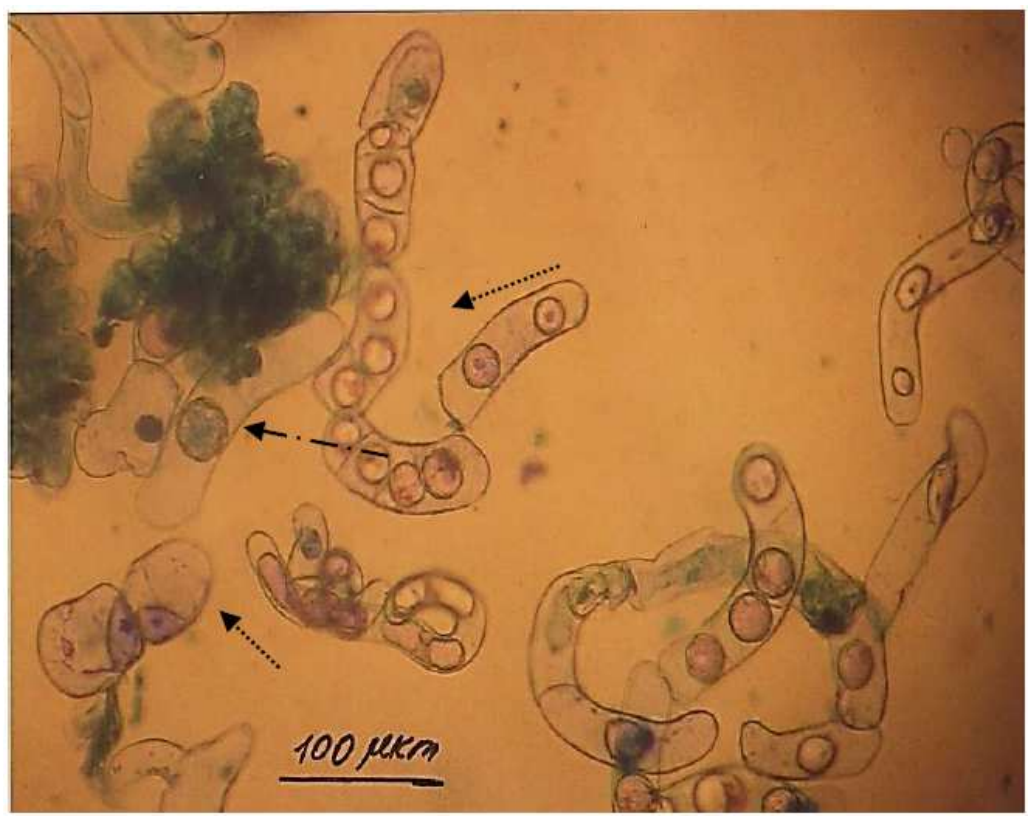

Fig. 9. Histological image of white opaque embryogenic (VI type) callus; $\longrightarrow$ single embryogenic cell; $\cdots \cdots \cdots \cdots \cdots \cdots \cdots \cdots \cdots$ pro-embryos; $-\cdot-\rightarrow$ elongated callus cells

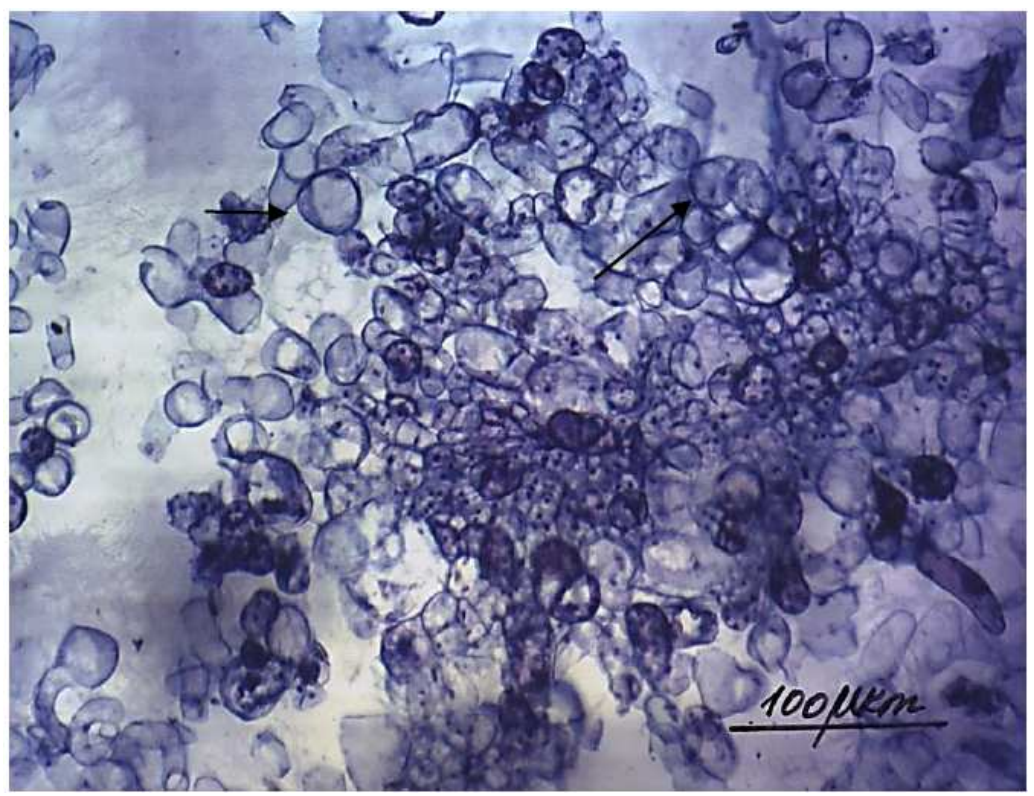

Fig. 10. Histological images of green compact embryogenic callus; $\longrightarrow$ competent to embryogenesis cells

Cell complexes of $\mathrm{V}$ type callus consist of meristematic center and parenchyma cells and cells with signs of cell death higher intensity of red-stained with Schiff reagent which indicating the changes in the nuclear material (Fig. 8a and 8b).

The image presented in Fig. 9 showed white opaque embryogenic VI callus content of single embryogenic cells (58-62 mkm) with callose, 2-, 3and 4-cell pro-embryos (96-150 mkm), Embryogenic
Cell Complexes (ECC) and elongated callus cells (158-187 mkm). Single embryogenic cells are rare, found most of 2-, 3- and 4-cell pro-embryos with prominent nucleus and dense cytoplasm. ECC consist from closely linked parenchyma cells.

In the structure of green compact embryogenic (VII type) callus observed ECC, elongated cells (66$92 \mathrm{mkm})$, competent to embryogenesis cells (25-32 mkm) (Fig. 10). 


\section{Discussion}

One of the main tasks of the modern plant biotechnology is to identify common cytophysiological regularities of in vitro morphogenesis universal for different cotton genotypes. Development of genotype independent technology of in vitro plant regeneration could be achieved on this base.

The conditions of callus formation in the culture of different explants (cotyledons, hypocotyls) of cotton varieties of Kazakh cotton varieties were optimized: (Maktaaral-4003, Maktaaral-4005, Maktaaral-4006, Maktaaral-4007, Maktaaral-4011, Maktaaral-4019, Pakhtaaral -3044) - MS media containing $0.5 \mathrm{mg} \mathrm{L}^{-1}$ kinetin and $0.1 \mathrm{mg} \mathrm{L}^{-1} 2,4 \mathrm{D}$.

Morphological heterogeneity and peculiarities of metamorphosis callus were studied. The grayish white friable (I type) of callus was identified as universal for different genotypes which is stable after repeated subculturing and promising in terms of morphogenesis.

During subculturing I grayish white type on primary tissue MS medium with twice the concentration of macronutrients, $1.0 \mathrm{mg} \mathrm{L}^{-1} 2,4-\mathrm{D}, 0.01 \mathrm{mg} \mathrm{L}^{-1}$ kinetin, $1000 \mathrm{mg} \mathrm{L}^{-1}$ casein hydrolyzate (GC), $500 \mathrm{mg} \mathrm{L}^{-1}$ proline and $3 \%$ maltose is its metamorphosis to form grayishwhite globular morphogenic callus (IV type). When I type subculture grayish-white type of primary tissue MS medium with twice the concentration of $\mathrm{KNO}_{3}$ and $3 \%$ maltose metamorphosis occurs to form a translucent yellowish friable embryogenic callus ( $\mathrm{V}$ type). When transferring type IV tissue on a medium with a single concentration of macronutrients formed white opaque embryogenic callus (VI type). When you save in the medium with double macronutrients formed tissue type VII - green compact embryogenic.

Comparative study of the morphology and structures of different types of calli of cotton indicates tissue types do not only differ in morphology, colours and consistency, also in structure, size of cells, presence or absence of somatic embryos and their development stages.

Peculiarities of the structure of various morphotypes of callus of local cotton varieties were identified. It has been shown that the grayish-white friable morphogenic callus (I type) composed parenchyma cells $(50-60 \mathrm{mkm})$ which covered by meristem cells $(20-25 \mathrm{mkm})$ and at the periphery of tissues were separated into elongated (105$147 \mathrm{mkm})$ and spherical cells $(30-50 \mathrm{mkm})$. The presence of meristem cells indicates morphogenetic potential of calli and their possibility to somatic embryogenesis induction.

Histological analysis indicated that the grayish-white friable morphogenic (I type) callus is morphologically stable and has perspective tissues with meristematic characteristics which designated as meristematic centers and embryogenic cells or somatic embryos absence.
The grayish-white globular morphogenic (IV type) callus contains globular somatic embryos and single competent to embryogenesis cells are the characteristic of embryogenic tissue and subsequently identified as embryogenic callus. Histological examination of IV type callus showed form of globular somatic embryo from tissue. Somatic embryos V, VI and VII types of embryogenic calli are at early step of developmentcompetent to embryogenesis cells and pro-embryos or pro-globular stage. Thus, histomorphological aspects of embryogenic and non-embryonic callus differs by presence or absence of competent to embryogenesis cells, somatic embryos and cells with signs of cell death.

Obtained long-term embryogenic callus tissue of local Kazakh cotton varieties, preserving the morphogenic potential in repeatedly subculturing which had the origin of the single-celled embryos.

There are not papers describing the earliest stages of cotton somatic embryogenesis. Earlier, the appearance of cell clumps aggregation of several thousand cells was revealed by histology of cotton tissue (Ganesan et al., 2006). They suggest that this aggregation of cells is an indication of the development of embryogenic calli subsequently the development of somatic embryo. In this study appearance of single embryogenic cells, proembryos, pro-globular and globular somatic embryos development were found in tissue culture of cotton.

\section{Conclusion}

In this study, we were able to perform induction of callus tissues from two explants (hypocotyl and cotyledon) of seven cotton cultivars on MS media with $0,1 \mathrm{mg} \mathrm{L}^{-1} 2,4-\mathrm{D}$ and $0,5 \mathrm{mg} \mathrm{L}^{-1}$ kinetin. The percentage of callus formation ranged from 64 to $91 \%$ and 72 to $90 \%$ for cotyledons and hypocotyl, respectively.

In tissue culture of all tested cotton cultivars, we identified seven types of calli (I - grayish-white friable morphogenic, II - off-white opaque dense nonmorphogenic, III - brown nonmorphogenic, IV grayish-white globular morphogenic, V - yellowish translucent friable embryogenic, VI - white opaque embryogenic and VII - green compact embryogenic) and conducted their histomorphological comparative study.

The morphological heterogeneity peculiarities of metamorphosis and histological structure of callus tissues of cotton have been studied. The metamorphosis of calli occurs during long-term subculture types of callus tissues. The grayish-white friable morphogenic (I type) callus exhibited a heterogeneous non embryogenic tissue and selected as a morphological stable and perspective for morphogenesis by the presence of meristem cells which indicates the morphogenetic potential of calli.

Upon subculture, type I calli on different somatic embryogenesis induction media transformed to embryogenic calli. Thus, we also suggest the response of 
plant cells to the change of media composition and the morphogenesis processes in vitro can be regulating.

Histological analysis of the grayish-white globular morphogenic (IV type) callus formed globular somatic embryos. Somatic embryos in embryogenic calli types V, VI and VII at earliest stage of development are capable of embryogenesis, pro-embryos, or pro-globular somatic embryos. Further research on the progress of developmental stages of somatic embryos in identified different types of embryogenic calli of cotton is necessary. Morphological observation and histological analysis have confirmed the embryogenic and non-embryonic callus characterized by presence or absence of cells capable of embryogenesis, somatic embryos and cells with signs of cell death.

In results, we have been created the recipient systems (cotyledon, hypocotyl, embryogenic callus) may be used for the genetic transformation of local cotton varieties.

\section{Acknowledgement}

Local cotton varieties were kindly provided by Dr. Umbetaev I.I. and Dr. Guseinov I.R. from the Cotton Growing Research Institute, Maktaaral, South Kazakhstan. Financial support provided by the Ministry of Education and Science of Government of Kazakhstan and by the National Center of Biotechnology of Republic of Kazakhstan.

\section{Funding Information}

Cotton biotechnology research is being funded by Government of Kazakhstan by STP C-082 of NCB RK.

\section{Author's Contributions}

Bishimbayeva Nazira: Fist author of the manuscript and supervisory role in this research work.

Yertayeva Bakhyt: Experimental design, conducted the experiment on hystologycal study of different calli types.

Aigul Amirova: Experimental design and participated in manuscript preparation and results discussion.

Rakhimbaev Izbasar: Supervized the study and participated in results interpretation.

\section{Ethics}

This article is original and contains unpublished material.

\section{References}

Bishimbayeva, N., B. Ertayeva, A. Amirova, I. Umbetayev and I. Rakhimbayev, 2007. The study of morphogenesis in tissue culture of elite cotton varieties of Kazakhstan. World Cotton Research Conference-4, Lubbock, TX, USA.
Davidonis, G.H. and R.H. Hamilton, 1983. Plant regeneration from callus tissue of Gossypium hirsutum L. Plant Sci. Lett., 32: 89-93.

DOI: $10.1016 / 0304-4211(83) 90102-5$

Ganesan, K.N., K. Thiruvengadam, D. Sudhakar, T.S. Raveendran and P. Balasubramanian, 2006. A histological tool to assess the progress of somatic embryogenesis in cotton (Gossypium hirsutum L.). Topical Asrieultuml Res. Extens., 9: 73-81.

Ghasemi, B.K., G.I. Karlov and A. Ahmadikhah, 2007. Effects of genotype, explant type and nutrient medium components on canola (Brassica napus L.) shoot in vitro organogenesis. Afr. J. Biotechnol., 6: 861-867.

Ghaemi, M., A. Majd, F. Fallahian and B.K. Ghasemi, 2011. Comparison of callus induction and somatic embryogenesis of some Iranian cottons (Gossypium Spp.) with Coker 312 and histology of somatic embryogenesis. Afr. J. Biotechnol., 10: 2915-2922. DOI: $10.5897 / \mathrm{AJB} 10.2229$

Ghasemi, B.K., Z. Bay and A. Behrooz, 2011. The effects of hormonal components of nutrient medium, cultivar and explant type on cotton (Gossypium hirsutum L.) callus formation in vitro. J. Applied Biosci., 47: 3256-3263.

Hilarie, K.T., K. Mongomake, K. Daouda, K.Y. Justin and N.G. Georges et al., 2008. Trans-resveratrol as phenolic indicator of somatic embryogenesis induction in cotton (Gossypium hirsutum L.) cell suspensions. Afr. J. Biochem. Res., 2: 015-023.

Ikram-ul-Haq, 2005. Callus proliferation and somatic embryogenesis in cotton (Gossypium hirsutum L.). Afr. J. Biotechnol., 4: 206-209.

Jiménez, V.M., 2001. Regulation of in vitro somatic embryogenesis with emphasis on to the role of endogenous hormones. Rev. Bras. Fisiol. Veg., 13: 196-223. DOI: 10.1590/S0103-31312001000200008

Kamelina, O.P., O.B. Proskurina and N.A. Zhinkina, 1992. To the method of coloring of embryological preparations. Bot. J.., 77: 93-96.

Kumria, R., V.G. Sunnichan, D.K. Das, S.K. Gupta and V.S. Reddy et al., 2003. High-frequency somatic embryo production and maturation into normal plants in cotton (Gossypium hirsutum) through metabolic stress. Plant Cell Rep., 21: 635-639. DOI: $10.1007 / \mathrm{s} 00299-002-0554-9$

Murashige, T. and F. Skoog, 1962. A revised medium for rapid growth and bioassays with tobacco tissue cultures. Physiol. Plantarum, 15: 473-497.

Pausheva, Z.P., 1988. Practical work on plant cytology. Agropromizdat, Moscow.

Price, H.J. and R.H. Smith, 1979. Somatic embryogenesis in suspension cultures of Gossypium klotzschianum anderss. Planta, 145: 305-307. DOI: $10.1007 / \mathrm{BF} 00454456$ 
Rajasekaran, K., H.F. Sakhanokho, A. Zipf, S. Saha and G.C. Sharma et al., 2004. Somatic embryo initiation and germination in diploid cotton (Gossypium arboreum L.). In Vitro Cell Dev. Biol. Plant., 40: 177-181. DOI: 10.1079/IVP2003497

Sakhanokho, H.F., P. Ozias-Akins, O.L. May and P.W. Chee, 2004. Induction of somatic embryogenesis and plant regeneration in select Georgia and Pee Dee cotton lines. Crop Sci., 44: 2199-2205. DOI: 10.2135/cropsci2004.2199

Vasil, I.K., 1987. Developing cell and tissue culture systems for the improvement of cereal and grass crops. J. Plant Physiol., 128: 193-218.

DOI: $10.1016 / \mathrm{S} 0176-1617(87) 80234-1$
Williams, E.G. and G. Maheswaran, 1986. Somatic embryogenesis: Factors influencing coordinated behaviour of cells as an embryogenic group. Ann. Bot., 45: 705-708.

DOI: 10.1093/oxfordjournals.aob.a087127

Wilkins, T.A., K. Rajasekaran and D.M. Anderson, 2000. Cotton biotechnology. Crit. Rev. Plant Sci., 19: 511-550. DOI: 10.1016/S0735-2689(01)80007-1

Wu, J., X. Zhang, Y. Nie and X. Luo, 2005. Highefficiency transformation of Gossypium hirsutum embryogenic calli mediated by Agrobacterium tumefaciens and regeneration of insect-resistant plants. Plant Breed., 124: 142-146.

DOI: $10.1111 /$ j.1439-0523.2004.01056.x 